\title{
Under Review: Timo Maran. Ecosemiotics: The Study of Signs in Changing Ecologies (Cambridge: Cambridge University Press, 20201
}

Sara Bédard-Goulet

DOI: https://doi.org/10.7592/methis.v22i27/28.18453

Keywords: ecosemiotics, ecosystems, modelling, nature writing

In his recent addition to the Cambridge Elements of Environmental Humanities series, Timo Maran offers a detailed presentation of ecosemiotics and how it successfully extends the scope of the study of signs to ecological systems. His Ecosemiotics: The Study of Signs in Changing Ecologies argues that this branch of semiotics highlights the connection between phenomena that are usually considered to belong to different domains, such as nature and culture. Ecosemiotics would thus provide relevant concepts and tools to examine the often-detrimental relationship between humans and nonhumans, and to initiate cultural practices that are beneficial to the environment.

The argument in Ecosemiotics is developed in three sections. The first section underlines the semiotic character of ecosystems by focusing on the relational processes between organisms and the environment. By presenting the semiotic realm that surrounds human culture and explaining how we interact with it, this section reveals that some ecological problems are semiotic ones, for example in case of interference with other species. While there are authors (Morizot 2020; Zhong Mengual 2021) who blame the current ecological crisis on the human relationship to other life forms and lack of sensitivity towards living beings, Maran convincingly demonstrates a potential semiotic cause for ecological problems. Indeed, the notions that he presents, such as Umwelt (Uexküll 1982), perceptual affordances (Gibson 1979) and ecofield (Farina and Belgrano 2004), support a conception of the landscape as a set of resources perceivable through interfaces together with a range of species that relate to this habitat on the basis of their needs (Maran 2020, 8). This ecosemiotic perspective insists on a tight interweaving of animal species and the environment and, in turn, on the required plasticity of the semiotic relations that the former have with the latter in the face of changing ecologies. Regarding animals, Maran reminds us that their sign-based communication is mediated, agential and open, which makes interspecies communication possible, including also human animals, even when the latter ignore the voice and meaning of ecosystems. The first section of the book ends with a brief exploration of ecosystemic semiosis 
in which semiotic processes take part in the regulation of biological communities, forming numerous feedback cycles that provide relative stability to ecosystems.

The second section of Ecosemiotics presents an ecosemiotic reply to the anthropocentrism that characterizes modernity by showing how cultures based on distancing from the natural environment lead to the impoverishment of ecosystems. From the point of view of semiotics, the dominant symbolic signs in culture, which are self-sufficient, receive too little negative feedback that would connect them to objects. Building on Alf Hornborg's (2001) typology of signs, Maran shows how linguistic, and especially economic, signs are standardized and abstract, leading to the subordination of nature to abstract values or measures that shape human activities regardless of the plurality of signs and meanings of other species. Such a symbolic hegemony of humans disrupts ecosystems and their inhabitants: semiotic pollution, for instance, increases stress in organisms, whereas semiocide, "a situation in which signs and stories that are significant for someone are destroyed because of someone else's malevolence or carelessness, thereby stealing a part of the former's identity" (Puura 2013, 152), can destroy nature's signscape.

Nevertheless, cultural systems are not entirely self-sufficient and they sustain connections with ecosystems. Referring to Jesper Hoffmeyer's work (1996), Maran points out how the semiotic processes of human cognition vary according to bodily conditions, in which meaningless signs retrospectively come to bear meaning - a process Michael Polanyi (1966) calls tacit knowledge. Conversely, symbols interact with ecosystems and their inhabitants, thus overcoming the representation - object divide, particularly through indexicality, which disturbs the boundaries between the index and the symbol, as well as those between human and nonhuman sign systems. As such, nature writing ties semiotic actors and (textual and environmental) subjectivities together via indexical references, forming what Maran calls a naturetext (Maran 2007; Maran and Tüür 2017). Building on Juri Lotman's understanding of communication, he argues that dialogical relations with the environment, which involve differences and depend upon non-symbolic signs, are essential for the wellbeing of cultures. Indeed, in a way comparable to Gilbert Simondon's encounters (2017), these interactions contribute to disrupting the symbolic order (Serres 2007) and bridging the epistemological gap between thought and body (Bateson and Bateson 1988), pointing out the importance of hybrid (Callon, Lascoumes and Barthe 2009) and multispecies communities (Maran 2020b).

The third section of Ecosemiotics addresses the potential connections between cultural objects and semiosis in the ecosystem. More specifically, it discusses semiotic modelling and how it takes place, how semiotic models work and affect culture-nature relationships, while it also examines the prescriptive potential of 
modelling, especially as regards artistic and creative forms. It starts by presenting key elements of Juri Lotman's semiotics in connection with ecosystems, starting with the concept of semiosphere, "a semiotic space of cultural texts, processes and interactions" (Maran 2020, 42), and introduces three ideas of Lotman's cultural semiotics: 1) autocommunicative capacities of culture; 2) semipermeable boundaries between cultural and extracultural spaces; and 3) space as a semiotically active entity (Maran 2020a, 43-47). Maran then moves on to Lotman's idea of a modelling system, "a structure of elements and rules of their combination, existing in a state of fixed analogy to the whole sphere of the object of perception, cognition, or organization" (Lotman 2011, 250). Because it combines symbolic signs, iconic resemblance and indexical references, modelling can be considered a type of translation based on a particular ground, with which it interacts. In connection with nature writing, Maran (2014) has previously proposed a distinction between zoosemiotic, linguistic, and artistic modelling, suggesting that the first type "creates a phenomenological presence for the reader" (Maran 2020a, 52), the second takes on a referential function, while the third one conveys, through aesthetic and narrative means, the author's perspective. The third section of Ecosemiotics ends with a presentation of the semiotic model of the forest as an alternative to models based on human grounds and a way for reconnecting cultures and ecosystems (Maran 2019). Maran identifies five characteristics of the forest as a model that would allow to describe the properties of an object of analysis: 1) distributed communication codes; 2) tolerance of meaning; 3) local heterogeneity and creativity; 4) strong ontological presence; 5) surplus of semiotic material (Maran 2020, 55-58).

The book's afterword closes on a hopeful note, touching on the potential of ecosemiotics and its creative approaches of modelling to bring along renewed engagement with the Anthropocenic ecosystems. This Cambridge Element of Environmental Humanities certainly offers a clear picture of the paths opened up by ecosemiotics as regards changing ecologies, with various phenomena that still require attention, such as nonanimal organisms, whose intricate relationship with their ecosystems would certainly provide a valuable perspective on semiosis. It can be argued that one of ecosemiotics' strengths regarding both the human and the nonhuman lies in its consideration of indexicality as a means to disrupt symbolic signs. It is effectively coupled with an attentiveness to bodies in their connection with cognition and, in the case of humans, conscious mind - a reflection that could benefit from including the unconscious mind, especially in view of ecosemiotics' concern with dialogic relations and the other. All in all, Ecosemiotics shows the rigorous concepts and methodology that ecosemiotics builds on and develops further in order to study sign processes of ecological phenomena. 


\section{Refere nces}

Bateson, Gregory, and Mary Catherine Bateson. 1988. Angels Fear: Towards an Epistemology of the Sacred. Cresskill: Hampton Press.

Callon, Michel, Pierre Lascoumes, and Yannick Barthe. 2009. Acting in an Uncertain World: An Essay on Technical Democracy. Cambridge, MA: Massachusetts Institute of Technology Press.

Farina, Almo, and Andrea Belgrano. 2004. “The Eco-field: A New Paradigm for Landscape Ecology." Ecological Restoration 19: 107-10. https://doi.org/10.1111/j.1440-1703.2003.00613.x.

Gibson, James J. 1979. The Ecological Approach to Visual Perception. New Jersey: Lawrence Erlbaum.

Hoffmeyer, Jesper. 1996. Signs of Meaning in the Universe. Bloomington: Indiana University Press.

Hornborg, Alf. 2001. "Vital Signs: An Ecosemiotic Perspective on the Human Ecology of Amazonia." Sign Systems Studies 29 (1): 121-52. https://doi.org/10.12697/sss.2001.29.1.09.

Lotman, Juri. 2011. “The Place of Art Among Other Modelling Systems.” Sign Systems Studies 39 (2/4): 249-70. https://doi.org/10.12697/sss.2011.39.2-4.10.

Maran, Timo. 2007. "Towards an Integrated Methodology of Ecosemiotics: The Concept of NatureText." Sign Systems Studies 35 (1/2): 269-94. https://doi.org/10.12697/sss.2007.35.1-2.10.

Maran, Timo. 2014. “Biosemiotic Criticism: Modelling the Environment in Literature." Green Letters: Studies in Ecocriticism 18 (3): 297-311. https://doi.org/10.1093/oxfordhb/9780199742929.013.008.

Maran, Timo. 2019. “Deep Ecosemiotics: Forest as a Semiotic Model”. Recherches sémiotiques/ Semiotic Inquiry 39 (1-2): 287-303. https://doi.org/10.7202/1076237ar.

Maran, Timo. 2020a. Ecosemiotics: The Study of Signs in Changing Ecologies. Cambridge: Cambridge University Press.

Maran, Timo. 2020b. “Ecological Repertoire Analysis: A Method of Interaction-Based Semiotic Study for Multispecies Environments". Biosemiotics 13 (1): 63-75. https://doi.org/10.1007/ s12304-020-09378-9.

Maran, Timo, and Kadri Tüür. 2017. “From Birds and Trees to Texts: An Ecosemiotics Look at Estonian Nature Writing." In A Global History of Literature and the Environment, edited by John Parham and Louise Westling, 286-300. Cambridge: Cambridge University Press.

Morizot, Babtiste. 2020. Manières d'être vivant: Enquêtes sur la vie à travers nous. Arles: Actes Sud.

Polanyi, Michael. 1966. The Tacit Dimension. Chicago: The University of Chicago Press.

Puura, Ivar. 2013. “Nature in Our Memory." Sign Systems Studies 41 (1): 150-53. https://doi. org/10.12697/sss.2013.41.1.10.

Serres, Michel. 2007. The Parasite. Minneapolis: University of Minnesota Press.

Simondon, Gilbert. 2017. L'individuation à la lumière des notions de forme et d'information. Grenoble: Millon.

Uexküll, Jakob von. 1982. “The Theory of Meaning." Semiotica 42: 25-82.

Zhong Mengual, Estelle. 2021. Apprendre à voir: Le point de vue du vivant. Arles: Actes Sud. 
Sara Bédard-Goulet - ASTRA Professor of Romance studies at the University of Tartu. Her transdisciplinary research focuses on contemporary art and Frenchlanguage literature, which she examines from the perspectives of ecocriticism and geopoetics, reader-response theory, and psychoanalysis.

e-mail: sara.bedard-goulet[at]ut.ee

Sara Bédard-Goulet on Tartu Ülikooli ASTRA programmi romanistika professor. Tema transdistsiplinaarne uurimistöö keskendub nüüdiskunstile ja prantsuskeelsele kirjandusele, mida ta on käsitlenud ökokriitika ja geopoeetika, lugeja vastuvõtu teooria ja psühhoanalüüsi perspektiividest.

e-post: sara.bedard-goulet[at]ut.ee 